\title{
Interaction of Selected Fuels with Water: Impact on Physical Properties and Microbial Growth
}

E. Kathryn Brown ${ }^{1}$, Mark Palmquist ${ }^{1}$, Luning Prak DJ1, Susan S Mueller ${ }^{2}$, Loryn L Bowen ${ }^{2}$, Kurt Sweely ${ }^{1}$, Oscar N Ruiz ${ }^{3}$ and Paul C Trulove ${ }^{1 *}$

${ }^{1}$ Department of Chemistry, US Naval Academy, Annapolis, MD 21402, USA

${ }^{2}$ University of Dayton Research Institute, University of Dayton, Dayton, OH 45469, USA

${ }^{3}$ Fuels and Energy Branch, Aerospace Systems Directorate, Air Force Research Laboratory, Wright-Patterson AFB, OH 45433, USA

\begin{abstract}
The incorporation of renewable fuels into the current fuel infrastructure requires a greater understanding of the impact of long term storage conditions of these fuels and their blends. In certain applications, especially those pertaining to the military, there is a high likelihood of exposure to marine environments, allowing for intimate mixing of fuels with water. Incorporation of water into fuels can lead to fuel degradation and enhance microbial contamination and growth, all of which impact storage and the ultimate usability of the fuels. Through the context of equilibrium water and dissolved salt concentration, properties of an algal hydrotreated renewable diesel (HRD), petroleum diesel (F76), soy-based fatty acid methyl esters (FAMEs) biodiesel and blends of 50/50 HRD/F76 and 5/95 FAME/F76 were investigated. Samples with the greatest equilibrium water content, the biodiesel and biodiesel blend, showed the highest incorporation of salts in samples unexposed to microbial growth. HRD, F76, and HRD/F76 blend samples were exposed to microbial growth and examined for selected physical properties and metals concentration. The blended HRD/F76 showed the highest microbial growth as well as the most metals carryover $\left(\mathrm{K}^{+}\right.$and $\left.\mathrm{Mg}^{2+}\right)$ of the samples investigated.
\end{abstract}

Keywords: Fatty acid methyl esters; Hydrotreated renewable diesel; Microbial growth; Carbon emissions

\section{Introduction}

Mounting concern over energy independence, reducing carbon emissions, and government mandates and incentives have led to a significant increase in the use of fuels derived from renewable sources, including biofuels, alternative fuels (drop-in fuels) and petroleumbio fuel blends [1-3]. Biodiesel, which is one of the most popular and commonly used biofuels, is composed of mono alkyl esters of fatty acids [4]; these fatty acid methyl esters (FAMEs) are produced through transesterification of fats or oils with alcohols and are most commonly catalyzed with base $[5,6]$. Hydrotreated renewable diesel (HRD), is a fuel produced from the same plant or animal oils as FAME biofuels, but they are catalytically processed to produce a drop-in hydrocarbon fuel similar to the conventional petroleum-derived fuel counterparts. These oils are hydrodeoxygenated and hydrodecarboxylated, $[7,8]$ producing long straight chain alkanes (n-C15 to n-C18) [6] and through isomerization lightly branched alkanes. HRD fuels have the advantage of high cetane values, $[7,8]$ and they can often be used as a drop-in replacement for petroleum based fuels in existing engines, making them an attractive alternative fuel for incorporation into the current fuel infrastructure. With the inclusion of renewable fuels into the fuel supply, considerations must be taken with respect to the impact these fuels will have on long-term fuel storage and usability. While HRD fuels meet the specifications for Naval distillate fuel (F76 diesel) [9] compositionally, the HRD fuels are significantly different than their petroleum analogues. This is of particular interest in marine applications where the potential for the interaction of fuels with water is probable. It has been established that compositional differences in fuel can impact water uptake and subsequent fuel degradation. In the case of FAME, the polar ester bonds make the fuel more hydrophilic than petroleum diesel, and equilibrium water content in these fuels has been shown to be much higher than petroleum diesel [10]. Due to the higher water content, FAME and a FAME/F76 blend were chosen in this study as a comparison for equilibrium studies, because it was hypothesized that a fuel with a greater capacity to hold water would also show a marked increase in dissolved metals when exposed to sterilized seawater. However, the interaction of HRD fuels with water is not well characterized. Furthermore, contact with a marine environment creates the potential for microbial growth and fuel degradation. Alternative fuels and their blends with conventional petroleum based diesel have been shown to promote microbial growth, [11-15] which can lead to corrosion issues within storage tanks and engines as well as cause filter clogging sludge and slime [16].

The impact of microbial growth due to contact with water in fuels is of particular interest in naval applications because salt water ballasting, depicted in Figure 1, is a practice commonly employed [17,18]. As fuel is consumed, seawater is pumped into the tank to maintain buoyancy. Fuel and seawater are in intimate contact for an extended period of time which allows for saturation of the fuel with seawater and the potential growth of microorganisms at the fuel water interface. This process introduces additional considerations into the assessment of the usability of bio-based alternative fuels. The intimate contact of fuel with seawater requires that adequate separation occurs because significant carryover of salts can have catastrophic effects on engine performance. This separation is controlled by chemical composition and can be heavily dependent on the presence of even trace constituents

*Corresponding author: Paul C Trulove, Department of Chemistry, US Naval Academy, Annapolis, MD 21402, USA, Tel: 410-293-6622; Fax: 410-293-2218; E-mail: trulove@usna.edu

Received September 01, 2014; Accepted December 30, 2014; Published January 10, 2015

Citation: Brown EK, Palmquist M, Luning Prak DJ, Mueller SS, Bowen LL, et al (2015) Interaction of Selected Fuels with Water: Impact on Physical Properties and Microbial Growth. J Pet Environ Biotechnol 6: 204 doi:10.4172/2157 7463.1000204

Copyright: $\odot 2015$ Brown EK, et al. This is an open-access article distributed under the terms of the Creative Commons Attribution License, which permits unrestricted use, distribution, and reproduction in any medium, provided the original author and source are credited. 


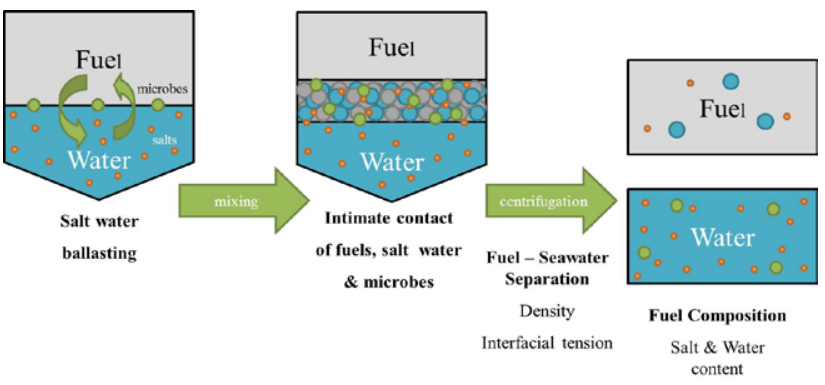

Figure 1: Cartoon depicting salt water ballasting and potential problems associated with salt water ballasting of alternative fuels and blends.

(e.g., surfactant molecules). The co-mingling of seawater and fuel also introduces the additional issue of microbial activity at the fuel-water interface [19-21] (Figure 1) and its potential to result in degradation of fuel properties [22] and bio-fouling [20]. It has been shown, that bacteria such as Pseudomonas aeruginosa and the marine bacteria Marinobacter hydrocarbonoclasticus can actively degrade multiple hydrocarbon compounds in F76 and jet fuel and produce dense biofilms [22,23]. Also, microorganisms produce metabolic by-products as they digest the fuel. These by-products, especially biosurfactants, can have surface active properties with the ability to significantly affect fuelseawater separation even when these components are present in ppm concentrations [24-26]. Adequate separation of fuel and seawater is heavily dependent on properties such as density and surface properties including interfacial tension and the inability to form stable emulsions over time. Consequently, even small increases in rates of microbial growth in bio-based fuels or blends over those for petroleum based fuels could result in significant increases in salt water carryover and an increase in engine degradation.

The goal of this research was to assess the impact of fuel/water contact on the selected properties of bio-based fuels and bio-petroleum fuel blends for marine applications. Microbially exposed samples were evaluated by examining the bulk properties of viscosity, density, surface tension, and interfacial tension, as well as metals carryover into the fuel. These properties were compared to military specification for naval distillate fuel [9] as a means of assessing their usability after exposure to microbial growth. Techniques and protocols for water exposure and equilibrium water and low concentration dissolved metals content in fuels were developed to determine the impact microbial growth may have on water and metals carryover in exposed fuels. Prior to this work, determination of $\mathrm{Mg}^{2+}$ and $\mathrm{K}^{+}$in fuels was limited to the part per million (ppm) and high part per billion (ppb) ranges [27-29].

Both $\mathrm{Mg}^{2+}$ and $\mathrm{K}^{+}$in fuel samples were analyzed because they are among the major cations found in seawater, [29] representing both monovalent and divalent cations for comparison, and they are less easily tainted by environmental contaminants than are $\mathrm{Ca}^{2+}$ and $\mathrm{Na}^{+}$. By developing these methods for detection and finding the baseline metals contents, both in unexposed fuels and those equilibrated with de-ionized water and sterilized seawater, the foundation has been laid for determining the specific impact of the interaction of alternative fuels with seawater and how this may impact water and salt carryover.

\section{Experimental Section}

All fuel samples were used as received from the vendor. The F76 petroleum diesel, algal-based hydrotreated renewable diesel (algal HRD), and a mixture containing equal volume of the two (50/50 F76/
Algal HRD 76) were provided by the Naval Fuels and Lubricants Cross Function Team at Patuxent River, Maryland. The algal HRD was produced by Solazyme and refined by Honeywell UOP to match the military specifications, [9] while containing only linear and branched alkanes [30]. Solazyme uses environmentally-controlled reaction vessels to grow proprietary algae. Honeywell UOP utilizes a propriety catalyst to remove the heteroatoms and saturate the double bonds of the algal oil and then isomerizes and selectively cracks the resulting products to increase the distribution of components. The FAME type biodiesel was Soy Gold B100 (AG Environmental Products LLC). In addition to the using the fuels as supplied, a mixture containing $5 \%$ by volume biodiesel in petroleum diesel (5/95 biodiesel F76) was prepared to match the highest percentage of biodiesel allowed in diesel fuel found in the European Union. Seawater was collected in Key West, Florida, and filtered through $0.45 \mu \mathrm{m}$ and $0.22 \mu \mathrm{m}$ Gelman Pal filters in order to sterilize the waters [31]. 18.1 $\mathrm{M} \Omega$ deionized water was obtained from a MilliQ filtration system.

\section{Water content}

Water content was measured by Karl Fisher titration (MettlerToledo DL-39 Coulometer). From a previously developed method [32], it was determined that a mixture of $70 \%$ Karl Fisher titrant by volume (Aquastar Combicoulomat fritless, EMD Chemicals) and 30\%, by volume, hexanol (Sigma Aldrich, anhydrous $\geq 99 \%$ ) increases the solubility of the fuels in the titrant without impacting the accuracy of the instrument. Prior to measurement, the instrument was calibrated by running both a high, $1.0 \mathrm{mg} / \mathrm{g}$ (Fluka hydranal $\mathrm{H}_{2} \mathrm{O}$ standard) and low, $0.1 \mathrm{mg} / \mathrm{g}$ (Fluka hydranal $\mathrm{H}_{2} \mathrm{O}$ standard) water standard. All samples were run in triplicate.

\section{Water equilibration}

To determine the water content, batch mixing experiments were conducted in $40 \mathrm{~mL}$ borosilicate glass vials ( $\mathrm{C}$ and $\mathrm{G}$ Containers) that had been pre-cleaned in the factory using protocol $\mathrm{A}$, which prepares the containers for use with metal analysis, and sealed with Teflon ${ }^{\circ}$ screw caps. Ten milliliters of fuel and ten milliliters of the aqueous phase were pipetted into each vial. Duplicate vials of each mixture were shaken on a Labquake tube shaker (Barnstead International) at room temperature. A rate study, shown in Figure 2, revealed that equilibrium was achieved in less than 10 minutes for biodiesel. For all the other fuels investigated samples reached equilibrium water content within five minutes. For all subsequent experiments, the vials were shaken

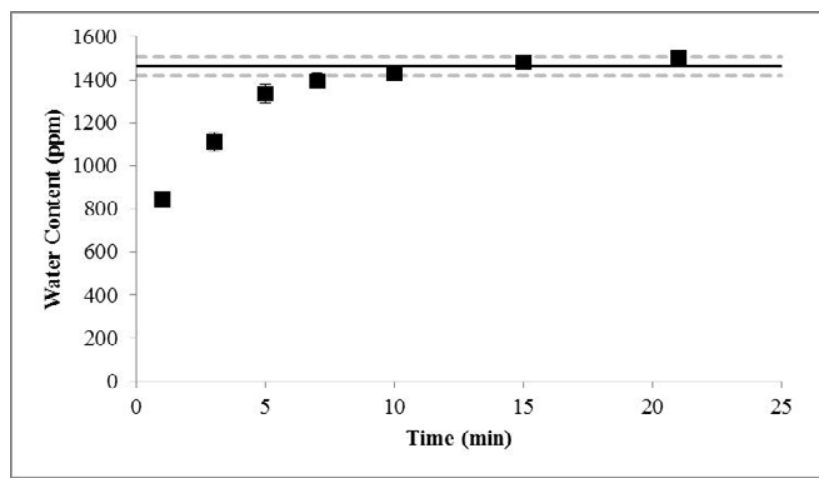

Figure 2: Impact of mixing time on water content for biodiesel with 18.1 M $\Omega$ water. (ם)

Samples taken at various shaking times. (---) Average value of equilibrium sample shaken for $>48$ hours (within 1 standard deviation). 
until equilibrium was reached. After shaking, the vials were centrifuged for $3 \mathrm{~min}$ at $3000 \mathrm{rpm}$ using an IEC Centra CL2 Centrifuge (Thermo Electron Corporation).

\section{Microbial exposure}

Tests were performed to characterize the effects of bacteria growth on the specification properties of three military hydrocarbon fuels; U.S. military petroleum diesel (F76), hydro-processed renewable dieselderived from algae (HRD) and a 50/50 volume percent ratio (v/v) blend of F76/HRD (Blend). The bioassays were comprised of a non-polar layer formed by $15 \mathrm{~mL}$ of fuel and $15 \mathrm{~mL}$ aqueous layer containing $50 \%(\mathrm{v} / \mathrm{v})$ autoclaved Key West seawater and 50\% (v/v) Bushnell-Haas media in 50 $\mathrm{mL}$ conical tubes. The aqueous layer of the test samples were inoculated with the marine bacteria Marinobacter hydrocarbonoclasticus, Rhodovulum sp., and Halobacillus sp., designated as sea microbes, at a starting concentration of $0.01 \mathrm{OD}_{600}$ each; total concentration 0.03 ODs. Negative control (Control) samples had the same content as the test samples but without bacteria. All tests were run in triplicate. Tubes containing the test and control samples were incubated for 28 days at $26^{\circ} \mathrm{C}$ in a shaker incubator at $150 \mathrm{rpm}$ (to promote oxygen transfer to the interface, but not disturb the biofilm formation). Experiments were conducted at $26^{\circ} \mathrm{C}$ to minimize oxidative fuel degradation; maintaining the integrity of the fuel was essential so small changes in properties due to microbial exposure could be measured. Previous work has shown that all three microorganisms, Marinobacter hydrocarbonoclasticus, Rhodovulum sp., and Halobacillus sp., grow well at $26^{\circ} \mathrm{C}$ [22].

\section{DNA extraction and quantification}

$100 \mu \mathrm{L}$ of seawater/BH were removed and treated with the MOBIO UltraClean ${ }^{\circledR}$ Microbial DNA Isolation Kit in order to extract DNA. The DNA was analyzed by qPCR using the $16 \mathrm{~S} r r n$ gene assay to obtain the bacterial load in each sample. Briefly, the qPCR was accomplished by using the CFX96 touch real time PCR detection system (Bio Rad, Hercules CA) with a two-step amplification program with postamplification melt curve analysis, as previously described [33]. The PCR amplification reaction included $6.5 \mu \mathrm{L}$ of IQ ${ }^{\mathrm{TM}}$ SYBR Green reaction mix, $200 \mathrm{nM}$ of forward and reverse $16 \mathrm{~S} \mathrm{rr}$ gene universal primers [34,35] $2.5 \mu \mathrm{L}$ of DNA and $3.5 \mu \mathrm{L}$ of nuclease free water. A synthetic oligonucleotide standard spanning the amplicon region was used for quantification [33]. The synthetic oligonucleotide was serialdiluted from $1 \times 10^{8}$ copies $/ \mu \mathrm{L}$ to $1 \times 10^{4}$ copies $/ \mu \mathrm{L}$ and used as a standard for absolute quantification.

\section{Metals analysis}

Water equilibrated samples and microbially exposed samples were analyzed for ppb metal analysis $\left(\mathrm{Mg}^{2+}, \mathrm{K}^{+}\right)$using a graphite furnace atomic absorption spectrometer (GFAA Perkin Elmer AAnalyst 800). These metals were selected because magnesium is the second most abundant metal present in seawater $(\sim 0.13 \%$ by mass $)$ and potassium is the $4^{\text {th }}$ most abundant component $(\sim 0.04 \%$ by mass). These metals can be used as an evaluative tool to estimate total salt concentrations in the fuels. Samples were prepared as microemulsions using a method modified from the literature for flame and graphite furnace analysis of fuels for trace metals [36-42]; using $2.5 \mathrm{~mL}$ twice distilled (in-house to enhance purity) reagent grade $n$-propanol ( $99.5 \%$ Sigma-Aldrich), 0.5 $\mathrm{mL}$ of the desired fuel, and $100 \mu \mathrm{L}$ of $0.2 \%\left(\mathrm{v} / \mathrm{v}\right.$ in deionized $\mathrm{H}_{2} \mathrm{O}$ ) trace metals grade $70 \% \mathrm{HNO}_{3}$ (Sigma-Aldrich). All volumes added were massed as well for enhanced precision in measurements. In GFAA analysis, a sample is dried, pyrolyzed, and then atomized by heating to various temperatures before atomic absorption is measured. The
GFAA instrument slit width $(0.7 \mathrm{~L})$, wavelength $\left(285.2 \mathrm{~nm}\right.$ for $\mathrm{Mg}^{2+}$ and $766.5 \mathrm{~nm}$ for $\mathrm{K}^{+}$), and atomization temperatures (Table 1) were standard values recommended by instrument literature. The time and temperature for the drying and pyrolysis steps were optimized for the micro-emulsion mixtures tested herein and are given in Table 1.

Sample injection volume was $5 \mu \mathrm{L}$ for $\mathrm{Mg}^{2+}$ and $\mathrm{K}^{+}$samples. All sample vials (Nalgene), pipette tips and GFAA sample cups were soaked in nitric acid (10\% v/v in DI water) and then rinsed seven times with $18.1 \mathrm{M} \Omega$ water and dried prior to use.

Metals concentrations in microemulsions were determined using the method of standard addition. In this method, a known amount of metal is introduced into the microemulsion through the aqueous phase as a dissolved salt. $\mathrm{KCl}$ (99.999\% trace metals basis, Aldrich) and $\mathrm{MgCl}$ (99.99\% trace metals basis, Aldrich) were dried overnight at $120^{\circ} \mathrm{C}$ under vacuum and transferred to an $\mathrm{N}_{2}$ dry box for storage. Dried salts were weighed into cleaned dried vials and dilutions with known concentrations were prepared with $0.2 \% \mathrm{HNO}_{3}$. These solutions of known concentrations were added as the $100 \mu \mathrm{L}$ aqueous phase portion of the microemulsion. All samples contained the same volume fraction of each component, $0.2 \% \mathrm{HNO}_{3}$, n-propanol, and fuel to maintain a consistent matrix. Standard addition curves were prepared from the known concentration of dissolved metal and the instrument response.

\section{Viscosity and density}

An SVM 3000 Stabinger Viscometer (Aton Paar) was used to measure the viscosity and density of the fuels. A certified reference standard, S3 Standard Oil (Cannon Instrument Company) was used to test the accuracy of the viscometer/densitometer in the range of 1.1512 to $4.673 \mathrm{~mm}^{2} / \mathrm{s}$ and 0.8063 to $0.8620 \mathrm{~g} / \mathrm{cm}^{3}$ for viscosity and density, respectively. If the viscosity deviated by greater than $1 \%$ or the density deviated by greater than $0.1 \%$ from the specified reference values, the instrument was cleaned and retested. Measurements were made at $20,40,60,80$ and $100^{\circ} \mathrm{C}$. Values reported are the average of replicate measurements, with standard deviations below $0.01 \mathrm{~mm}^{2} / \mathrm{s}$ for viscosity and $0.0001 \mathrm{~g} / \mathrm{cm}^{3}$ for density unless otherwise noted.

\section{Surface and interfacial tension}

A Kruss DS100 axisymmetric drop shape analyzer was used to measure the surface tension of the F76, algal HRD and a 50/50 F76/ HRD blend. In this measurement, a droplet of the fuel phase is formed in air and an image taken. The droplet shape is fitted with the YoungLaPlace equation using the densities of the fuel phase and air $[43,44]$.

\begin{tabular}{|l|c|c|c|c|}
\hline & $\begin{array}{c}\text { Temp } \\
\left({ }^{\circ} \mathbf{C}\right)\end{array}$ & $\begin{array}{c}\text { Ramp } \\
\text { Time } \\
(\mathbf{s})\end{array}$ & $\begin{array}{c}\text { Hold } \\
\text { Time } \\
(\mathbf{s})\end{array}$ & $\begin{array}{c}\text { Internal } \\
\text { Flow } \\
(\mathbf{m L} / \mathbf{m i n})\end{array}$ \\
\hline $\mathbf{M g}^{\mathbf{2 +}} \mathbf{5} \boldsymbol{\mu L}$ injection volume & \multicolumn{1}{|c|}{} \\
\hline drying & 80 & 1 & 30 & 250 \\
\hline drying & 120 & 15 & 60 & 250 \\
\hline drying & 500 & 40 & 30 & 250 \\
\hline pyrolysis & 900 & 10 & 20 & 250 \\
\hline atomization & 1900 & 0 & 5 & 0 \\
\hline clean & 2450 & 1 & 3 & 250 \\
\hline $\mathbf{K}^{+} \mathbf{5} \boldsymbol{\mu L}$ injection volume & 110 & 1 & 30 & 250 \\
\hline drying & 130 & 15 & 30 & 250 \\
\hline drying & 900 & 10 & 20 & 250 \\
\hline pyrolysis & 1500 & 0 & 5 & 0 \\
\hline atomization & 2450 & 1 & 3 & 250 \\
\hline clean & & & & \\
\hline
\end{tabular}

Table 1: Graphite Furnace Steps for Metals Analysis. 
Over fifteen measurements were taken for three droplets of each liquid.

The interfacial tension values were determined for fuels and aqueous phases that were equilibrated prior to measurement. For samples that had been exposed to bacteria, no additional equilibration was done with water, since they had been previously mixed with an aqueous phase.

For the samples not involving bacteria, each fuel was mixed with an equal volume of the aqueous phase $(10$ or $15 \mathrm{~mL})$ in $40-\mathrm{mL}$ borosilicate glass vials sealed with Teflon ${ }^{\circ}$ screw caps. The vials were shaken on a Labquake tube shaker (Barnstead International) at room temperature for at least 24 hours to reach equilibrium. Then they were allowed to settle before the aqueous phase was transferred to a cuvette and the fuel to a syringe for use in the drop shape analyzer. For surface tension and interfacial tension measurements, impurities can alter the measurements, so the syringes and cuvettes were cleaned by washing and soaking for at least 15 minutes in methanol, 15 minutes in acetone, and $15 \mathrm{~min}$ in $18.1 \mathrm{M} \Omega \mathrm{H}_{2} \mathrm{O}$ prior to drying in an oven at $110^{\circ} \mathrm{C}$. The cuvettes were additionally soaked for more than 15 minutes in NoChromix (Godax Laboratories, Inc.). A similar washing procedure was recommended by Demond et al. [45].

\section{Results and Discussion}

In order to assess the impact of salt water ballasting on fuels of varying composition, first samples were exposed to $18.1 \mathrm{M} \Omega$ water and sterilized Key West seawater in the absence of microorganisms. Conducting experiments without microbial action allows for the assurance that all samples have reached equilibrium water concentrations under the given reaction conditions and establishes a baseline for sample comparison.

\section{Water content}

To ensure all samples had reached equilibrium prior to water content and trace metals analysis, the time to reach equilibrium for the fuel with the highest water content (the soy-based biodiesel) was determined, as shown in Figure 2. Samples were taken at various shaking times and analyzed for water content and compared to a sample at equilibrium (shaken for greater than 48 hours). For biodiesel, the water content increased with increased shaking time until the samples had been shaken for 10 minutes. After 10 minutes, the water content remained constant and was comparable, within the error of the measurement, to the 48 hour equilibrium samples as shown in Figure 2. For all other fuels investigated, equilibrium was reached within 5 minutes.

The equilibration of the various fuels with water increased their water content, and the enhancement depended on fuel as shown in Figure 3. The biodiesel had a high water content before equilibrating with water (neat sample), $329 \mathrm{ppm}$, and this value increased considerably after equilibrating with water (1460 ppm for samples equilibrated with 18.1 $\mathrm{M} \Omega$ water and $1400 \mathrm{ppm}$ for samples equilibrated with KWSW). Such high water contents have been seen by other researchers [11]. Biodiesel is more hydrophilic than conventional diesel [46] due to the presence of ester groups, [11] which can hydrogen bond with water allowing for a higher equilibrium water content. The HRD had the lowest water contents, less than $50 \mathrm{ppm}$ for both neat (not equilibrated with water) and water equilibrated samples, of the fuels and fuel mixtures studied. Due to the chemical composition of HRD (predominantly straight chain and lightly branched, mono and dimethyl, alkanes) [47,48] its affinity for water is lower than that of conventional diesel which contains a wider array of components such as aromatic compounds

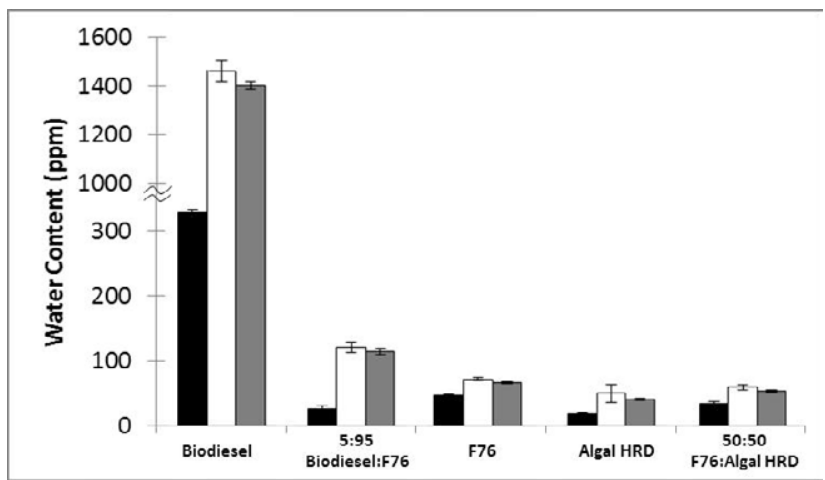

Figure 3: Water content in fuel samples equilibrated with $(\square)$ ultra-pure water $(18.1 \mathrm{M} \Omega),(\square)$ Key West seawater (KWSW), and without water or $(\square)$ neat fuel. Error bars shown are 1 standard deviation.

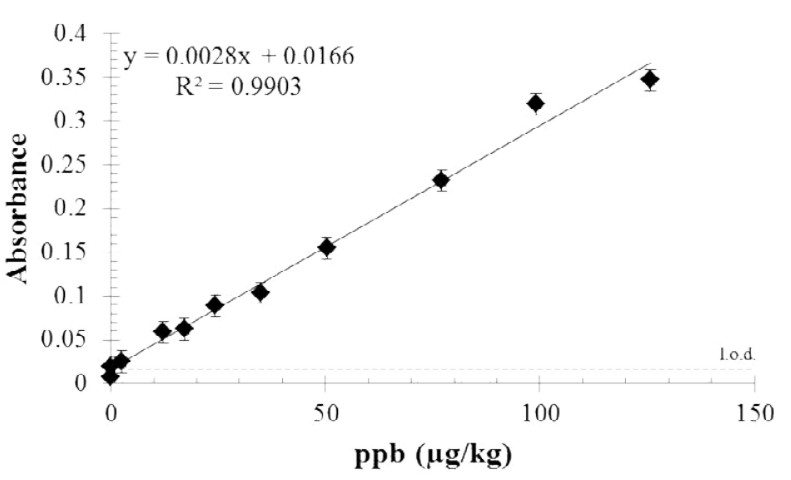

Figure 4: Standard addition curve for $\mathrm{Mg}^{2+}$ in Algal HRD.

that are more hydrophilic [15]. For the mixtures, the equilibrium water content values are additive from the pure components, within the error of the measurements, and fall in between the values of the pure components. For example, a mixture containing $50 \%$ volume of F76 in Algal HRD (50/50 F76/HRD) had a water content of 54 ppm, which was half way between the values for F76, $67 \mathrm{ppm}$, and HRD, $41 \mathrm{ppm}$. When comparing the type of water used in the equilibration, there was no statistical difference in water content between the samples of HRD, F76, or a 5\% by volume FAME in F76 when exposed to Key West seawater (KWSW) and those exposed to ultra-pure water (18.1 $\mathrm{M} \Omega$ ). For both the FAME and 50/50 F76/HRD, the water content of the samples equilibrated with $18.1 \mathrm{M} \Omega$ water were higher than that of KWSW (p-value $<<0.05,95 \%$ confidence interval).

\section{Metals content}

After determining the equilibrium water content, trace metal partitioning into the fuel phase was examined. Graphite furnace atomic absorption methods were developed for both magnesium $\left(\mathrm{Mg}^{2+}\right)$ and potassium $\left(\mathrm{K}^{+}\right)$as discussed in the experimental section. To determine the concentration of metal, a standard addition curve was made for each fuel to ensure that matrix effects did not interfere with measurements. As shown in Figure 4 for algal HRD, the addition of specified concentration of a $\mathrm{Mg}^{2+}$ standard increases the detector response linearly. Extrapolation of the curves to the y-intercept gives the metal concentration in the microemulsion. The dashed line represents the limit of detection (l.o.d.) of this technique for a given analyte and 
Citation: Brown EK, Palmquist M, Luning Prak DJ, Mueller SS, Bowen LL, et al. (2015) Interaction of Selected Fuels with Water: Impact on Physical Properties and Microbial Growth. J Pet Environ Biotechnol 6: 204. doi:10.4172/2157-7463.1000204

Page 5 of 8

fuel. The coefficients and residual values from the linear regression of the standard addition curves are given in Table 2 for both potassium and magnesium analysis. The remaining standard additional curves can be found in the Supporting Information.

A comparison of the metal content in fuels before (neat) and after exposure to water shows that only some of the fuels equilibrated with Key West seawater (KWSW) exhibited statistically significant increases in dissolved metals concentration ( $\mathrm{p}$ value $<0.05,95 \%$ confidence interval) from the neat, unexposed fuel. All metals concentrations are given in Table 3. Statistically significant increases in metals concentration are shown in bold. Biodiesel samples showed the highest increase in dissolved metals content, with the increase from the neat in $\mathrm{Mg}^{2+}$ being much higher than that of $\mathrm{K}^{+}, 53.7 \pm 5.1$ and $5.0 \pm 1.4$ $\mathrm{ppb}$, respectively, for samples exposed to KWSW. The increase in $\mathrm{Mg}^{2+}$ concentration in petroleum F76 upon exposure to seawater was smaller than that of biodiesel, $10.1 \pm 5 \mathrm{ppb}$, while no change was found in potassium. For the 5/95 blend of FAME/F76, the increase in $\mathrm{Mg}^{2+}$ was similar to that of the F76, $9.9 \pm 3 \mathrm{ppb}$ in $\mathrm{Mg}^{2+}$ concentration from the unexposed fuel after equilibration with KWSW.

While the presence of the small amount of FAME in the mixture resulted in higher water content as discussed previously, it did not have a significant impact on metal carryover. Due to the lower concentration of $\mathrm{K}^{+}$and the limited solubility of $\mathrm{K}^{+}$in F76, there was no detectable increase in $\mathrm{K}^{+}$concentration in the 5/95 blend. The algal HRD did not exhibit any change in its metal content after exposure to water. In the 50/50 blend of F76/Algal HRD, the in $\mathrm{Mg}^{2+}$ concentration after equilibration with KWSW increased by $13.9 \pm 5 \mathrm{ppb}$, which is similar to the F76 alone. No other samples showed statistically significant changes after equilibration, which are in agreement with increases in water content, indicating that the metals are carried over in the solubilized water. To further assess the impact of metals carryover, samples were exposed to microbial growth by fuel degrading microorganisms to determine if microbial action would have an impact on dissolved metals concentration.

\section{Microbial exposure}

The impact of microbial growth in petroleum diesel has been previously investigated [22] but growth in HRD fuels has not been well characterized. In this work, HRD, F76, and a 50/50 blend of HRD/ F76 were exposed to a mixture of fuel degrading bacteria isolated from seawater, Marinobacter hydrocarbonoclasticus, Rhodovulum sp., and Halobacillus sp. The growth of these bacteria was monitored for 18 days by qPCR using $16 \mathrm{~S}$ rrn gene primers. Growth was determined at $0,6,12$, and 18 days as shown in Figure 5. The growth in both the F76 and the 50/50 F76/algal HRD blend was similar, while growth in the algal HRD was significantly lower. These differences in microbial growth counts are likely due to the compositional differences of the fuel. Algal HRD is comprised mainly of $n$-alkanes and isoparrafins from C15-C18. Shorter chain alkanes and aromatics are present only in very small quantities. F76 on the other hand contains a much wider array of components, including shorter chain alkanes and aromatics. Marinobacter is known to preferentially degrade $\mathrm{n}-\mathrm{C} 9$ to $\mathrm{n}-\mathrm{C} 12$ alkanes and ethylbenzene with

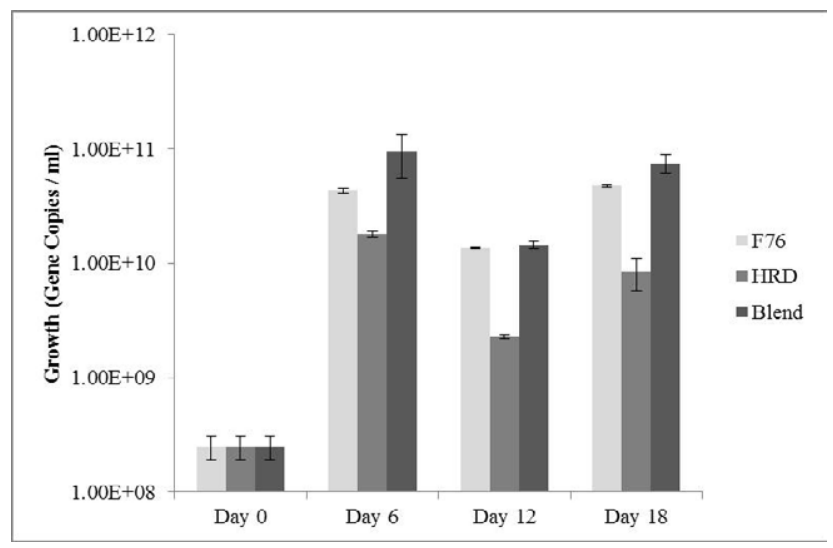

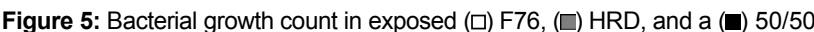
F76/HRD blend.

\begin{tabular}{|c|c|c|c|c|c|c|c|c|c|c|}
\hline & \multicolumn{2}{|c|}{ F76 } & \multicolumn{2}{|c|}{$\begin{array}{l}\text { Algal } \\
\text { HRD }\end{array}$} & \multicolumn{2}{|c|}{$\begin{array}{c}50: 50 \\
\text { F76:Algal HRD }\end{array}$} & \multicolumn{2}{|c|}{ Biodiesel } & \multicolumn{2}{|c|}{$\begin{array}{c}\text { 5:95 } \\
\text { Biodiesel:F76 }\end{array}$} \\
\hline & $\mathrm{Mg}^{2+}$ & $\mathrm{K}^{+}$ & $\mathrm{Mg}^{2+}$ & $\mathrm{K}^{+}$ & $\mathrm{Mg}^{2+}$ & $\mathrm{K}^{+}$ & $\mathrm{Mg}^{2+}$ & $\mathrm{K}^{+}$ & $\mathrm{Mg}^{2+}$ & $\mathrm{K}^{+}$ \\
\hline slope & 0.0031 & 0.0026 & 0.0028 & 0.0022 & 0.0026 & 0.0028 & 0.0026 & 0.0035 & 0.0024 & 0.0016 \\
\hline intercept & 0.0097 & 0.0044 & 0.0166 & 0.0036 & 0.0267 & 0.0001 & 0.0491 & 0.0013 & 0.0083 & 0.0018 \\
\hline $\mathbf{R}^{2}$ & 0.9903 & 0.9908 & 0.9903 & 0.9667 & 0.9855 & 0.9715 & 0.9501 & 0.9856 & 0.9919 & 0.9969 \\
\hline
\end{tabular}

Table 2: Coefficients and residual values from linear regression of calibration data for ppb level analysis of magnesium and potassium in fuels.

\begin{tabular}{|c|c|c|c|c|c|}
\hline & $\mathrm{K}^{+}(\mathbf{p p b})$ & $\mathrm{Mg}^{2+}(\mathrm{ppb})$ & & $\mathrm{K}^{+}(\mathbf{p p b})$ & $\mathrm{Mg}^{2+}(\mathrm{ppb})$ \\
\hline \multicolumn{3}{|c|}{ F76 } & \multicolumn{3}{|c|}{ Biodiesel } \\
\hline Neat & $1.7 \pm 1.8$ & $3.1 \pm 5.4$ & Neat & $0.4 \pm 1.8$ & $18.9 \pm 7.8$ \\
\hline KWSW & $3.2 \pm 1.8$ & $13.2 \pm 5.2$ & KWSW & $5.4 \pm 1.4$ & $72.6 \pm 5.1$ \\
\hline $18.1 \mathrm{M} \Omega$ & $2.4 \pm 1.7$ & $5.2 \pm 5.3$ & $18.1 \mathrm{M} \Omega$ & $2.7 \pm 1.5$ & $26.7 \pm 6.8$ \\
\hline \multicolumn{3}{|c|}{ Algal HRD } & \multicolumn{3}{|c|}{ 5/95 Biodiesel/F76 } \\
\hline Neat & $1.6 \pm 1.8$ & $5.9 \pm 4.9$ & Neat & $1.1 \pm 1.0$ & $2.6 \pm 2.5$ \\
\hline KWSW & $4.5 \pm 2.1$ & $8.8 \pm 4.9$ & KWSW & $2.8 \pm 0.9$ & $12.5 \pm 1.5$ \\
\hline $18.1 \mathrm{M} \Omega$ & $3.4 \pm 2.1$ & $10.02 \pm 4.9$ & $18.1 \mathrm{M} \Omega$ & $2.3 \pm 0.9$ & $2.9 \pm 1.6$ \\
\hline \multicolumn{3}{|c|}{ 50/50 F76/Algal HRD Blend } & & & \\
\hline Neat & $0.4 \pm 2.2$ & $10.3 \pm 4.7$ & & & \\
\hline KWSW & $2.4 \pm 2.3$ & $24.2 \pm 4.1$ & & & \\
\hline $18.1 \mathrm{M} \Omega$ & $2.0 \pm 2.3$ & 13. \pm 4.4 & & & \\
\hline
\end{tabular}

*Error bars are one standard deviation

Table 3: Metal concentrations in ppb of the control, unexposed (Neat) and for samples equilibrated with Key West seawater (KWSW) and 18.1 M $\Omega$ water. 
no detectable degradation of longer C14 to C23 alkanes observed [22]. Due the lack of preferential food sources in HRD, the growth of microorganisms in this fuel is much lower than the growth in F76. In the $50 / 50$ blend, the F76 provides enough of the desired components for microbial growth, giving comparable growth in the blend to F76 alone.

As a metric for determining the impact this growth had on the fuels, the bulk physical properties of density, viscosity, and surface tension, which are important for the transport and combustion of these fuels, were determined before and after microbial exposure to the sea microbes. In all fuel samples, the viscosity and density did not show any significant change when exposed to microbial growth as shown in Table 4 for $40^{\circ} \mathrm{C}$. (Tables for the full temperature range of viscosity and density are given in the Supplemental Information). For example, for the algal HRD, the density in the neat, unexposed fuel is $0.7635 \mathrm{~g} / \mathrm{cm}^{3}$. The density of the control samples for microbial exposure is 0.7634 $\mathrm{g} / \mathrm{cm}^{3}$. After exposure to degradation by sea microbes, the density of the fuel was $0.7636 \mathrm{~g} / \mathrm{cm}^{3}$. These values are all unchanged within the standard deviation of the measurement $\left(0.0001 \mathrm{~g} / \mathrm{cm}^{3}\right)$. Viscosity of fuels after microbial exposure was also unchanged. For example, at $40^{\circ} \mathrm{C}$, the viscosity of neat, unexposed HRD is $2.80 \mathrm{~mm}^{2} / \mathrm{s}$. The control sample for microbial exposure has a viscosity of $2.82 \mathrm{~mm}^{2} / \mathrm{s}$. After degradation, the fuel exposed to sea microbes had a viscosity of 2.83 $\mathrm{mm}^{2} / \mathrm{s}$. This result is not surprising because viscosity and density are not likely to be impacted by the presence of small amounts of impurities. After exposure, both viscosity and density values for all fuels met the specification [9] for viscosity; $1.7<\mathrm{X}<4.3 \mathrm{~mm}^{2} . \mathrm{s}^{-1}$ at $40^{\circ} \mathrm{C}$ and a density of less than $0.876 \mathrm{~g} \cdot \mathrm{mL}^{-1}$ at $15^{\circ} \mathrm{C}$.

Properties such as surface tension and particularly interfacial tension (Table 5) can be impacted by the presence of small amounts of metabolically generated surface active impurities such as biosurfactants [24-26] or bio-films [49-51]. For all the fuels investigated, there was no change in surface tension between the control sample, which contains the same growth media as the samples with microbes, and the corresponding microbially exposed sample. Any small changes in fuel composition due to degradation and metabolic by-product formation were not significant enough to impact the surface tension of the fuels. When comparing the surface tension of each neat fuel with the samples exposed water, the surface tension decreases slightly, but the change is not significant. The impact of the growth of microorganisms on the interfacial tension varied with fuel. For the F76 and 50/50 F76/ $\mathrm{HRD}$, the differences between the control and the samples containing microbes were small and were within one standard deviation as shown in Table 5. In contrast, the interfacial tension between HRD and water was impacted by microbial growth. Exposure to microbes caused a drop in interfacial tension.

Degradation by the sea microbes caused the interfacial tension to drop from $37.1 \mathrm{dyn} / \mathrm{cm}$ in the control sample to $33.0 \mathrm{dyn} / \mathrm{cm}$ after exposure. Biosurfactants at low concentration have been shown to lower the surface tension of alkanes more than aromatic compounds. Huang and Shreve [52] report plots showing that a rhamnolipid biosurfactant in low concentrations did not change the interfacial tension between toluene and the surfactant solution, with values around $30 \mathrm{dyn} / \mathrm{cm}$. In contrast, at this same biosurfactant concentration the interfacial tension between the surfactant solution and dodecane dropped from 34 to $26 \mathrm{dyn} / \mathrm{cm}$. At higher concentrations of surfactant where toluene interfacial tension had decreased by $7 \mathrm{dyn} / \mathrm{cm}$ and the benzene interfacial tension by $5 \mathrm{dyn}$, iso-octane interfacial tension declined by approximately $22 \mathrm{dyn} / \mathrm{cm}$ and dodecane by $17 \mathrm{dyn} / \mathrm{cm}$. In their studies, interfacial tension of alkanes were more significantly affected by the presence of small amounts of rhamnolipids than was the inter facial tension of aromatics. Due to the sensitivity of alkanes and iso-alkanes to the presence of small amounts of biosurfactant when compared to aromatic compounds, a larger drop in interfacial tension in the HRD fuel is observed. Although there were slight variations in both the surface and interfacial tension, these changes did not strongly correlate with metals carryover, or microbial growth as the most growth was seen in the 50/50 F76/HRD blend.

The impact of microbial exposure on metals content also depended on the fuel and the microorganisms. Table 6 gives the dissolved potassium or magnesium in neat fuel, control samples, and after microbial exposure. Samples showing increased metals content after exposure are in bold, and other samples did not show statistically

\begin{tabular}{|c|c|c|c|c|c|c|}
\hline & \multicolumn{3}{|c|}{ Density $\left(\mathrm{g} / \mathrm{cm}^{3}\right)$} & \multicolumn{3}{|c|}{ Kinematic Viscosity $\left(\mathrm{mm}^{2} / \mathrm{s}\right)$} \\
\hline & Neat & $\begin{array}{c}\text { Control } \\
\text { Sea Microbes }\end{array}$ & $\begin{array}{c}\text { Sea } \\
\text { Microbes }\end{array}$ & Neat & $\begin{array}{c}\text { Control } \\
\text { Sea Microbes }\end{array}$ & $\begin{array}{c}\text { Sea } \\
\text { Microbes }\end{array}$ \\
\hline F76 & 0.8350 & 0.8353 & 0.8352 & 2.90 & 2.97 & 2.95 \\
\hline $\begin{array}{c}50 / 50 \\
\text { F76/Algal HRD }\end{array}$ & 0.7995 & 0.7993 & 0.7999 & 2.86 & 2.88 & 2.87 \\
\hline Algal HRD & 0.7635 & 0.7634 & 0.7636 & 2.80 & 2.82 & 2.83 \\
\hline
\end{tabular}

*Standard deviation is $0.01 \mathrm{~mm}^{2} / \mathrm{s}$ for viscosity and $0.0001 \mathrm{~g} / \mathrm{cm} 3$ for density

Table 4: Density and Viscosity of F76, $50 / 50$ blend of F76/Algal HRD, and Algal HRD at $40^{\circ} \mathrm{C}$ before and after Exposure to Microbial Degradation.

\begin{tabular}{|c|c|c|c|c|c|c|}
\hline & \multicolumn{2}{|c|}{ F76 } & \multicolumn{2}{|c|}{$\begin{array}{c}50 / 50 \\
\text { F76/Algal HRD }\end{array}$} & \multicolumn{2}{|c|}{ Algal HRD } \\
\hline & $\begin{array}{l}\text { Surface Tension } \\
(\text { dyn/cm })\end{array}$ & $\begin{array}{l}\text { Interfacial Tension with } \\
\text { KWSW }(\text { dyn/cm) }\end{array}$ & $\begin{array}{l}\text { Surface Tension } \\
(\text { dyn/cm })\end{array}$ & $\begin{array}{c}\text { Interfacial Tension with } \\
\text { KWSW (dyn/cm) }\end{array}$ & $\begin{array}{c}\text { Surface Tension } \\
(\text { dyn/cm })\end{array}$ & $\begin{array}{c}\text { Interfacial Tension with } \\
\mathrm{KWSW}(\mathrm{dyn} / \mathrm{cm})\end{array}$ \\
\hline $\begin{array}{c}\text { Neat } \\
\text { (Unexposed) }\end{array}$ & $28.2 \pm 0.1$ & $10.7 \pm 0.4$ & $26.8 \pm 0.2$ & $13.0 \pm 0.6$ & $26.0 \pm 0.1$ & $34.6 \pm 1.0$ \\
\hline $\begin{array}{c}\text { Control } \\
\left(\mathrm{KWSW} / \mathrm{BH}^{*}\right)\end{array}$ & $26.7 \pm 0.3$ & $13.5 \pm 0.1$ & $25.8 \pm 0.1$ & $16.7 \pm 0.2$ & $25.2 \pm 0.2$ & $37.1 \pm 0.3$ \\
\hline Sea Microbes & $26.7 \pm 0.2$ & $12.3 \pm 0.2$ & $25.7 \pm 0.1$ & $18.1 \pm 0.2$ & $25.1 \pm 0.2$ & $33.0 \pm 1.5$ \\
\hline
\end{tabular}

${ }^{*}$ Error is one standard deviation. ${ }^{*}$ Control sample contains the same media as sea microbe sample (50/50 Key West seawater/Bushnell Haas media), but is sterile and has not been inoculated with sea microbes.

Table 5: Surface and Interfacial Tension of Fuels before and after Microbial Exposure. 
Citation: Brown EK, Palmquist M, Luning Prak DJ, Mueller SS, Bowen LL, et al. (2015) Interaction of Selected Fuels with Water: Impact on Physical Properties and Microbial Growth. J Pet Environ Biotechnol 6: 204. doi:10.4172/2157-7463.1000204

Page 7 of 8

\begin{tabular}{|c|c|c|c|c|c|c|c|c|c|}
\hline & \multicolumn{3}{|c|}{ F76 } & \multicolumn{3}{|c|}{ Algal HRD } & \multicolumn{3}{|c|}{$\begin{array}{l}\text { 50/50 F76/Algal } \\
\text { HRD Blend }\end{array}$} \\
\hline & Neat & $\begin{array}{c}\text { Control } \\
\text { (KWSW/BH) }\end{array}$ & $\begin{array}{c}\text { Sea } \\
\text { Microbes }\end{array}$ & Neat & $\begin{array}{c}\text { Control } \\
\text { (KWSW/BH) }\end{array}$ & $\begin{array}{c}\text { Sea } \\
\text { Microbes }\end{array}$ & Neat & $\begin{array}{c}\text { Control } \\
\text { (KWSW/BH) }\end{array}$ & $\begin{array}{c}\text { Sea } \\
\text { Microbes }\end{array}$ \\
\hline $\mathrm{K}^{+}(\mathrm{ppb})$ & $1.7 \pm 1.8$ & $12.3 \pm 2.3$ & $12.9 \pm 2.4$ & $1.6 \pm 1.8$ & $9.3 \pm 3.0$ & $8.7 \pm 3.0$ & $0.4 \pm 2.2$ & $7.0 \pm 2.9$ & $11.6 \pm 2.8$ \\
\hline $\mathrm{Mg}^{2+}(\mathrm{ppb})$ & $3.1 \pm 5.4$ & $165.8 \pm 14.9$ & $156.4 \pm 14.3$ & $5.9 \pm 4.9$ & $5.1 \pm 4.9$ & $28.1 \pm 4.7$ & $2.6 \pm 2.5$ & $70.0 \pm 6.4$ & $178.9 \pm 9.3$ \\
\hline
\end{tabular}

*Error bars are one standard deviation

Table 6: Metals content (ppb) after exposure to microbial action.

significant changes. The HRD and HRD/F76 blend exposed to sea microbes, Marinobacter hydrocarbonoclasticus, Rhodovulum sp. and Halobacillus showed a significant increase in magnesium concentration (Table 6), with an increase of $108.9 \mathrm{ppb}$ and $23.0 \mathrm{ppb}$ for the 50/50 F76/HRD blend and HRD, respectively. This phenomena has been reported for mixtures of biodiesel with petroleum fuels, with certain blends showing a larger increase in microbial degradation than each fuel component alone [12,15]. Our data provides evidence that this may also be the case for HRD samples, shown by the increase in metals concentration and bacterial growth counts for the blend over either F76 or algal HRD.

\section{Conclusion}

Equilibration of fuel samples with ultra-pure and Key West seawater resulted in increased water content from neat fuels. The soybased FAME and its $5 \%(\mathrm{v} / \mathrm{v})$ blend with petroleum diesel had the greatest equilibrium water content of any of the fuels investigated, while the algal $\mathrm{HRD}$ and the 50/50 $\mathrm{HRD}$ /petroleum blend had the lowest equilibrium water content. Salt carryover correlated with water content; the samples showing the highest water content, also gave the highest salt concentrations. HRD, F76 and a 50/50 blend were exposed to microbial degradation by Marinobacter hydrocarbonoclasticus, Rhodovulum sp., and Halobacillus sp. and were examined for trace metals content. Our preliminary results found that the blend had the highest increase in microbial growth and metals concentration of the three, suggesting that the balance of the composition of the HRD and the F76 provide a better environment for the growth of Marinobacter hydrocarbonoclasticus, Rhodovulum sp., allowing it to have the greatest impact on the fuel, resulting in an increase in the dissolved metals concentration. The exposure to microorganisms did not affect the fuel properties of density, viscosity, and surface tension which are important for transport and combustion of fuel. The interfacial tension was lowered in the algal HRD, which may be caused by the fact it is predominantly composed of linear and branched alkanes, whose surface tensions are more sensitive to the presence of lower concentrations of surfactant than are aromatic hydrocarbons, which can be found in petroleum fuel. In order to more fully characterize the impact of microbial growth in hydrotreated renewable fuels, further studies will be needed.

\section{Acknowledgment}

The authors would like to thank the Office of Naval Research for funding of this work, and the United States Naval Academy and the Air Force Research Laboratory for providing personnel and facilities. Any opinions, findings, and conclusions or recommendations expressed in this material are those of the authors and do not necessarily reflect the views of the Office of Naval Research, the Air Force Research Laboratory, or the U. S. Naval Academy.

\section{References}

1. Sorda G, Banse M, Kemfert C (2010) An overview of biofuel policies across the world. Energy Policy 38: 6977-6988.

2. US Department of Energy. Alternative Fuels Data Center.
3. Van Noorden R (2013) EU debates U-turn on biofuels policy. Nature 499: 13-14.

4. Standard specification for biodiesel fuel blend stock (B100) for middle distillate fuels (2008) Report No D6751-08. ASTM 2008.

5. Ma F, Hanna MA (1999) Biodiesel production: a review. Bioresource Technology 70: 1-15.

6. Helwani Z, Othman MR, Aziz N, Fernando WJN, Kim J (2009) Technologies for production of biodiesel focusing on green catalytic techniques: A review. Fue Processing Technology 90: 1502-1514.

7. Naik SN, Goud VV, Rout PK, Dalai AY (2010) Production of first and second generation biofuels: A comprehensive review. Renewable and Sustainable Energy Reviews 14: 578-597.

8. Vonortas A, Papayannakos N (2014) Comparative analysis of biodiesel versus green diesel. WIREs Energy and Environment 3: 3-23.

9. United States Department of Defense (DOD) Performance Specification Fuel, Naval Distillate; DOD: Washington, D.C., Oct. 23, 2006; Military Specification MIL-PRF-16884L.

10. Fregolente PBL, Fregolente LV, Maciel MRW (2012) Water Content in Biodiesel, Diesel, and Biodiesel-Diesel Blends. Journal of Chemical and Engineering Data 57: 1817-1821.

11. He BB, Thompson JC, Routt DW, Van Gerpen JH (2007) Moisture absorption in biodiesel and its petro-diesel blends. Applied Engineering and Agriculture 23(1): 71-76

12. Sorensen G, Pedersen DV, Norgaard AK, Sorensen KB, Nygaard SD (2011) Bioresource Technology 102: 5259-5264.

13. Bucker F, Santestevan NA, Roesch LF, Jacques RJS, do Carmo Ruaro Peralba $\mathrm{M}$, et al. (2011) Impact of biodiesel on biodeterioration of store Brazilian diesel oil. International Biodeterioration and Biodegradation 65: 172-178.

14. Owsainiank M, Chrzanowski L, Sulc A, Staniewski J, Olszanowski A, et al. (2009) Biodegradation of diesel/biodiesel blends by a consortium of hydrocarbon degraders: Effect of the type of blend and the addition of biosurfactants. Bioresource Technology 100: 1497-1500.

15. Schleicher T, Werkmeister R, Russ W, Meyer-Pitroff R (2009) Microbiological stability of biodiesel-diesel-mistures. Bioresource Technology 100: 724-730.

16. Bento FM, Gaylarde CC (2001) Biodeterioration of stored diesel: studies in Brazil. International Biodeterioration and Biodegradation 47: 107-112.

17. Environmental Protection Agency (EPA). Phase I Final Rule and Technical Development Document of Uniform National Discharge Standards (UNDS) Washington, D.C., April, 1999; EPA-842-R-99-001.

18. Blank DA, Bock AE, Richardson DJ (2005) Introduction to Naval Engineering, 2nd Edition. United States Naval Institute, Annapolis.

19. Lee JS, Ray RI, Little BJ (2009) Microbiological and corrosivity characterizations of biodiesels and advanced diesel fuels. In: NACE International Corrosion Conference and Expo. Paper No. 09529, 1-22.

20. Lee JS, Ray RI, Little BJ (2010) Corrosion-related consequences of biodiese in contact with natural seawater. In: NACE International Corrosion 2010 Conference and Expo. 1-18.

21. Little BJ, Lee JS, Ray RI (2011) Corrosion in fuel/natural seawater environments. NRL/PP/7303-11-0668. Naval Research Laboratory, Stennis Space Center, MS.

22. Striebich RC, Smart CE, Gunasekera TS, Mueller SS, Strobel EM, et al. (2014) 
Citation: Brown EK, Palmquist M, Luning Prak DJ, Mueller SS, Bowen LL, et al. (2015) Interaction of Selected Fuels with Water: Impact on Physical Properties and Microbial Growth. J Pet Environ Biotechnol 6: 204. doi:10.4172/2157-7463.1000204

Characterization of F-76 diesel and Jet-A aviation fuel hydrocarbon degradation profiles of Pseudomonas aeruginosa and Marinobacter hydrocarbonoclasticus. International Bio deterioration and Biodegradation 93: 33-43.

23. Gunasekera TS, Striebich RC, Mueller SS, Strobel EM, Ruiz, ON (2013) Transcriptional profiling suggests that multiple metabolic adaptations are required for effective proliferation of Pseudomonas aeruginosa in Jet Fuel. Environmental Science and Technology 47: 13449-13458.

24. Mulligan CN (2005) Environmental applications for biosurfactants Environmental Pollution 133: 183-198.

25. Lang S (2002) Biological amphiphiles (microbial biosurfactants). Current Opinion in Colloid and Interface Science 7: 12-20.

26. Banat IM, Makkar RS, Cameotra SS (2000) Potential commercial applications of microbial surfactants. Applied Microbiology and Biotechnology 53: 495-508.

27. Barros Al, de Oliveira AP, de Magalhaes MRL, Villa RD (2012) Determination of sodium and potassium in biodiesel by flame atomic emission spectrometry, with dissolution in ethanol as a single sample preparation step. Fuel 93 381-384.

28. Chaves ES, Saint'Pierre TD, do Santos EJ (2008) Determination of $\mathrm{Na}$ and K in biodiesel by flame atomic emission spectrometry and microemulsion sample preparation. Journal of the Brazilian Chemical Society 19: 856-861.

29. Millero FJ (2006) Chemical Oceanography (3rdedn) CRC Press, Taylor and Francis Group. Boca Raton, FL.

30. Morris RE, Begue NJ (2011) Compositional comparison of algae derived diese fuels to their petroleum derived counterparts. SER 6180/0128. Naval Research Laboratory, Washington, DC.

31. Leifer A (1988) The Kinetics of Environmental Aquatic Photochemistry (ACS Professional Reference Books). American Chemical Society. Washington, DC.

32. Mettler TT (2004) DL32/DL39 Applications Brochure 32: Fundamentals of the Coulometeric Karl Fischer Titration with Selected Applications 22.

33. Ruiz ON, Fernando KAS, Wang B, Brown NA, Luo PG, et al. (2011) Graphene oxide: A nonspecific enhancer of cellular growth. ACS Nano 5: 8100-8107.

34. Maeda T, Maeda H, Yamabe K, Mineshiba J, Tanimoto I, et al. (2003) Highly expressed genes in a rough-colony-forming phenotype of Aggregatibacter actinomycetemcomitans: implications of a mip-like gene for the invasion of host tissue. FEMS Immunology and Medical Microbiology 39: 81-86.

35. Horz HP, Vianna ME, Gomes BPFA, Conrads G (2005) Evaluation of universa probes and primer sets for assessing total bacterial load in clinical samples: General implications and practical use in endodontic antimicrobial therapy. Journal of Clinical Microbiology 43: 5332-5337.

36. Jesus A, Silva MM, Vale MGR (2008) The use of microemulsion for determination of sodium and potassium in biodiesel by flame atomic absorption spectrometry. Talanta 74 : 1378-1384.

37. Lobo FA, Goveia D, de Oliveira AP, Pereira-Filho ER, Fraceto LF, et al. (2009) Comparison of the univariate and multivariate methods in the optimization of experimental conditions for determining $\mathrm{Cu}, \mathrm{Pb}, \mathrm{Ni}$ and $\mathrm{Cd}$ in biodiesel by GFAAS. Fuel 88(10): 1907-1914.

38. Vieira MA, de Oliveira LCC, Goncalves RA, de Souza V, de Campos RC (2009) Determination of As in vegetable oil and biodiesel by graphite furnace atomic absorption spectrometry. Energy and Fuels 23: 5942-5946.

39. de Jesus A, Zmozinski AV, Barbara, JA, Vale MGR, Silva MM (2010) Determination of calcium and magnesium in biodiesel by flame atomic absorption spectrometry using microemulsions as sample preparation. Energy and Fuels 24: 2109-2112.
40. Lyra FH, Carneiro MTWD, Brandao GP, Pessoa HM, de Castro EV (2010) Determination of $\mathrm{Na}, \mathrm{K}, \mathrm{Ca}$ and $\mathrm{MG}$ in biodiesel samples by flame atomic absorption spectrometry (F AAS) using microemulsion as sample preparation. Microchemical Journal 96: 180-185.

41. Silva JSA, Chaves ES, dos Santos EJ, Saint'Pierre TD, Frescura VLA, et al. (2010) Calibration techniques and modifiers for the determination of $\mathrm{Cd}, \mathrm{Pb}$ and $\mathrm{TI}$ in biodiesel as microemulsion by graphite furnace atomic absorption spectrometry. Journal of the Brazilian Chemical Society 21: 620-626.

42. Brandao GP, de Campos RC, Luna, AS, de Castro EVR, de Jesus HC (2006) Determination of arsenic in diesel, gasoline, and naptha by graphite furnace atomic absorption spectrometry using microemulsion medium for sample stabilization. Analytical and Bioanalytical Chemistry 385: 1562-1569.

43. Rotenberg Y, Boruvka L, Neumann AW (1983) Determination of surface tension and contact angle from the shapes of axisymmetric fluid interfaces. Journal of Colloid and Interface Science 1: 169-183.

44. Hansen FK, Rodsrud G (1991) Surface tension by pendant drop: I. A fast standard instrument using computer image analysis. Journal of Colloid and Interface Science 141: 1-9.

45. Demond AH, Desai FN, Hayes KF (1994) Effect of cationic surfactants on organic liquid-water capillary pressure-saturation relationships. Wate Resources Research 30: 333-342.

46. Bruno TJ, Baibourine E (2011) Comparison of biomass-derived turbine fuels with the composition-explicit distillation curve method. Energy and Fuels 25 1847-1858.

47. Luning-Prak DJ, Cowart JS, Hamilton LJ, Hoang DT, Brown EK, et al. (2013) Development of a surrogate mixture for algal-based hydrotreated renewable diesel. Energy and Fuels 27: 954-961.

48. Srivastava A, Prasad R (2000) Triglycerides-based diesel fuels. Renewable and Sustainable Energy Reviews 4: 111-133.

49. Baumgarten T, Sperling S, Seifert J, von Bergen M, Steiniger F, et al. (2012) Membrane vesicle formation as a multiple-stress response mechanism enhances Pseudomonas putida DOT-T1E cell surface hydrophobicity and biofilm formation. Applied Environmental Microbiology 78(17): 6217-6224.

50. Vu B, Chen M, Crawford RJ, Ivanova EP (2009) Bacterial Extracellular Polysaccharides Involved in Biofilm Formation. Molecules 14: 2535-2554.

51. Ramsey DM, Wozniak DJ (2005) Understanding the control of Pseudomonas aeruginosa alginate synthesis and the prospects for management of chronic infections in cystic fibrosis. Molecular Microbiology 56: 309-322.

52. Huang HH, Shreve GS (2001) Effect of the hydrocarbon phase on interfacia and thermodynamic properties of two anionic glycolipid biosurfactants in hydrocarbon/water systems. Journal of Physical Chemistry 105: 12596-12600. 